Pak. j. sci. ind. res. Ser. A: phys. sci. 201457 (3) 125-128

\title{
Kinetics and Mechanism of Ag (I) Catalysis in Peroxodisulphate Oxidation of Tris(2,2'-Bipyridine)Fe(II) in Aqueous Acid Media
}

\author{
Shazia Summer, Iftikhar Imam Naqvi* and Rasheeda Khatoon \\ Department of Chemistry, Jinnah University for Women, V-C, Nazimabad, Karachi-74600, Pakistan
}

(received October 2, 2012; revised March 13, 2013; accepted May 19, 2013)

\begin{abstract}
The kinetics of $\mathrm{Ag}^{+}$catalysed oxidation of tris $\left(2,2^{\prime}\right.$-bipyridine)iron(II) complex by the peroxodisulphate ion $\left(\mathrm{S}_{2} \mathrm{O}_{8}{ }^{2-}\right)$ in aqueous acidic media have been investigated spectrophotometrically at $\lambda_{\max } 522 \mathrm{~nm}$, the wavelength of maximum absorption of complex ion. It was determined that the rate of oxidation of $\left[\mathrm{Fe}\left(2,2^{\prime} \text {-bipyridine }\right)_{3}\right]^{2+}$ by $\mathrm{S}_{2} \mathrm{O}_{8}{ }^{2-}$ ion is independent of the concentration of $\left[\mathrm{Fe}\left(2,2^{\prime}-\right.\right.$ bipyridine) $\left.)_{3}\right]^{2+}$ and $\mathrm{H}^{+}$(within $\mathrm{pH}$ range of 3.8-4.8), but first order dependent with respect to the concentrations of $\mathrm{S}_{2} \mathrm{O}_{8}{ }^{2-}$ and $\mathrm{Ag}^{+}$in the $4.16 \times 10^{-4}-16.7 \times 10^{-4} \mathrm{~mol} / \mathrm{dm}^{3}$ and $4.16 \times 10^{-5}-16.7 \times 10^{-5} \mathrm{~mol} / \mathrm{dm}^{3}$ ranges, respectively. Experimental results confirm the validity of the suggested mechanism.
\end{abstract}

Keywords: kinetics, catalysis, persulphate, tris(2,2'-bipyridine)iron(II)

\section{Introduction}

The peroxodisulphate anion $\left(\mathrm{S}_{2} \mathrm{O}_{8}^{2-}\right)$ having standard reduction potential of $+2.1 \mathrm{~V}$ (Latimer, 1952), pertaining to electrode reaction, $\mathrm{S}_{2} \mathrm{O}_{8}^{2-}+2 \mathrm{e}^{-}=>2 \mathrm{SO}_{4}^{2-}$, is one of the strongest oxidants (Fordham and Williams, 1951). This is noteworthy that this potential is higher than that of the redox potentials for hydrogen peroxide $\left(\mathrm{H}_{2} \mathrm{O}_{2}\right)$ and permanganate anion $\left(\mathrm{MnO}_{4}^{-}\right)$, which are $1.8 \mathrm{~V}$ and $1.7 \mathrm{~V}$, respectively. Despite a very high reduction potential value its reaction kinetics is extremely slow. However, in presence of some catalysts, the kinetics of $\mathrm{S}_{2} \mathrm{O}_{8}^{2-}$ oxidation gets significantly, enhanced due to the formation of $\mathrm{SO}_{4}^{-*}$ radicals. Some of these catalysts include $\mathrm{Ag}$ (I), Mn (II), $\mathrm{Cu}$ (II), $\mathrm{Cr}$ (III) etc.

A large number of investigations regarding the kinetics of reactions involving peroxodisulphate have been reported since nineteenth century. The role of Ag (I) ion in peroxodisulphate oxidations was extensively focused by many researchers. Kinetics of decomposition of peroxodisulphate in presence of silver nitrate was investigated spectrophotometrically by Naim and Naqvi (1981). It has been found that the rate of decomposition of $\mathrm{S}_{2} \mathrm{O}_{8}^{2-}$ in presence of $\mathrm{Ag}(\mathrm{I})$ ion get enhanced greatly, and the reaction is first order dependent on the concentrations of $\mathrm{S}_{2} \mathrm{O}_{8}^{2-}$ and $\mathrm{Ag}^{+}$. The reaction was postulated to proceed via $\mathrm{S}_{2} \mathrm{O}_{8}^{2-}$ and $\mathrm{Ag}^{+}$interaction, as shown below:

$$
\mathrm{S}_{2} \mathrm{O}_{8}^{2-}+\mathrm{Ag}^{+} \longrightarrow \mathrm{SO}_{4}^{2-}+\mathrm{SO}_{4}^{--}+\mathrm{Ag}^{2+}
$$

Oxidation of several other reducing agents including oxalate, thiosulphate, Ce (IV), ammonia, ammonium ion, arsenious acid and hydrogen peroxide (House, *Author for correspondence; E-mail: Iftikhar.imam@yahoo.com
1962; Wilmarth and Haim, 1962) by peroxodisulphate in presence of $\mathrm{Ag}^{+}$ion have also been investigated and it was found that the kinetic order is first for both $\mathrm{S}_{2} \mathrm{O}_{8}^{2-}$ and $\mathrm{Ag}^{+}$but zero in reductant.

$\mathrm{Ag}^{+}$catalysed oxidation of carboxylic acids (Anderson and Kochi, 1969) and oxidations of alcohols and aromatic substrates (Walling and Camaioni, 1978) by $\mathrm{S}_{2} \mathrm{O}_{8}^{2-}$ have also been investigated and found to show the similar kinetic behaviour.

Kinetics of the influence of $\mathrm{Ag}^{+}$ions on the oxidation of $\left[\mathrm{Fe}(1,10-\text { phen })_{3}\right]^{2+}$ by peroxodisulphate in neutral medium has been investigated by Cyfert (1983). Experiments on $\mathrm{Ag}^{+}$catalysed oxidation of [Co(II) EDTA] by $\mathrm{S}_{2} \mathrm{O}_{8}^{2-}$ have also been reported (Begum and Rasheed, 2001). Both of these researchers have shown that the oxidation reactions are independent of reductant concentrations.

However, Busari et al. (2008) discovered $\mathrm{Ag}^{+}$catalysed oxidation of methylene blue (MB) by peroxodisulphate ion in aqueous nitric acid medium to be substrate concentration dependent, who observed that the reaction is first order dependent each on $\mathrm{Ag}^{+}, \mathrm{S}_{2} \mathrm{O}_{8}^{2-}$ and $\mathrm{MB}$ and proposed an outer-sphere mechanism. However, their data was insufficient to explain the role of the substrate (MB) in presence of $\mathrm{Ag}^{+}$and $\mathrm{S}_{2} \mathrm{O}_{8}^{2-}$.

The present investigation has been undertaken to fix the role of substrate $\left[\mathrm{Fe}\left(2,2^{\prime} \text {-bipyridine }\right)_{3}\right]^{2+}$ in the $\mathrm{Ag}^{+}$catalysed oxidation by peroxodisulphate $\left(\mathrm{S}_{2} \mathrm{O}_{8}^{2-}\right)$. The influence of various factors such as concentration of reagents, $\mathrm{pH}$ and ionic strength $(\mu)$ of medium, on the rate of oxidation are also being reported. This work is in continuation to our investigations pertaining to the 
role of $\mathrm{Mn}$ (II) and $\mathrm{Co}(\mathrm{II})$ as catalysts on oxidations by persulphate.

\section{Materials and Methods}

Chemicals and solutions. All chemicals including potassium peroxodisulphate $\left(\mathrm{K}_{2} \mathrm{~S}_{2} \mathrm{O}_{8}\right)$, silver nitrate $\left(\mathrm{AgNO}_{3}\right)$, sodium acetate $\left(\mathrm{CH}_{3} \mathrm{COONa}\right)$, acetic acid $\left(\mathrm{CH}_{3} \mathrm{COOH}\right)$, and sodium sulphate $\left(\mathrm{Na}_{2} \mathrm{SO}_{4}\right)$, were of $\mathrm{BDH}$ (AnalaR) grade. Double distilled and deionised water was used for preparation of the solutions. For the preparation of tris(2,2'-bipyridine)iron(II) sulphate the synthetic route (Taylor and Schilt, 1959) was adopted. Stoichiometry of complex was determined by mole ratio method and complex was characterised on the basis of uv/visible spectrum on Shimadzu-uv-visible spectrophotometer. Wavelength of maximum absorption was found to be $522 \mathrm{~nm}$, which is in good agreement with the available literature (Pryzstas and Sutin, 1973) and the molar extinction coefficient was determined to be $7876.8 \mathrm{dm}^{3} / \mathrm{mol} / \mathrm{cm}$ (Summer et al., 2009).

Solution of silver nitrate was prepared by adding measured quantities of silver nitrate in acidic buffer media. Standard solutions of potassium peroxodisulphate $\left(\mathrm{K}_{2} \mathrm{~S}_{2} \mathrm{O}_{8}\right)$ were prepared freshly before use to avoid any decomposition and by dissolving known quantities of reagent into deionised water. Solutions of sodium sulphate, acetic acid and sodium acetate were also prepared in deionised water.

Kinetic measurements. The kinetic study of oxidation of $\left[\mathrm{Fe}\left(2,2^{\prime} \text {-bipyridine }\right)_{3}\right]^{2+}$ by $\mathrm{S}_{2} \mathrm{O}_{8}{ }^{2-}$ catalysed by $\mathrm{Ag}^{+}$ ion was carried out under the conditions in which concentration of oxidant $\mathrm{S}_{2} \mathrm{O}_{8}{ }^{2-}$ were taken $10,20,30$ and 40 times greater than the corresponding iron (II) complex $\left[\mathrm{Fe}\left(2,2^{\prime} \text {-bipy }\right)\right]^{2+}$. Sodium acetate-acetic acid buffer was used to maintain the $\mathrm{pH}$ of the solution in the range of 3.8-4.8. $\mathrm{Na}_{2} \mathrm{SO}_{4}$ was used to maintain the ionic strength $(\mu)$ of the medium in the range $0.1-1.0 \mathrm{~mol} / \mathrm{dm}^{3}$. Various ratios of $\left[\mathrm{Fe}\left(2,2^{\prime} \text {-bipyridine }\right)_{3}\right]^{2+}, \mathrm{S}_{2} \mathrm{O}_{8}{ }^{2-}$ and $\mathrm{Ag}^{+}$were mixed in a $1 \mathrm{~cm}$ quartz cell to a total volume of $3 \mathrm{~mL}$.

The absorbance was monitored spectrophotometrically as a function of time for each set of reaction mixture at $522 \mathrm{~nm}$, the wavelength of maximum absorption of $\left[\mathrm{Fe}\left(2,2^{\prime} \text {-bipyridine }\right)_{3}\right]^{2+}$. Kinetic data was collected by using integration method, by plotting $\ln \left(\mathrm{At}_{\mathrm{t}} \mathrm{A} \infty\right)$ versus time. All the plots were found to be straight line with intercept. The temperature of the reaction mixture was controlled to $303 \mathrm{~K}$, by using Techne TE-8J, thermostat bath.

\section{Results and Discussion}

In preliminary examinations it was observed that the rate of oxidation of iron (II) complex ion by $\mathrm{S}_{2} \mathrm{O}_{8}{ }^{2-}$ was very slow in absence of $\mathrm{Ag}^{+}$ion. It was experimental that at fixed concentrations of $\left[\mathrm{Fe}\left(2,2^{\prime} \text {-bipy }\right)_{3}\right]^{2+}$ and $\mathrm{S}_{2} \mathrm{O}_{8}{ }^{2-}$ at $4.16 \times 10^{-5}$ and $4.16 \times 10^{-4} \mathrm{~mol} / \mathrm{dm}^{3}$, respectively, an increment in the concentration of the $\mathrm{Ag}^{+}$ion in the reaction mixture in the range $4.16 \times 10^{-5}-16.7 \times 10^{-5}$ $\mathrm{mol} / \mathrm{dm}^{3}$, significantly, increases the rate of oxidation, of $\left[\mathrm{Fe}\left(2,2^{\prime} \text {-bipy }\right)_{3}\right]^{2+}$ by $\mathrm{S}_{2} \mathrm{O}_{8}{ }^{2-}$ (Table 1$)$.

When the values of $\mathrm{k}_{\mathrm{obs}}$ for different sets of experiments were plotted as a function of concentration of $\mathrm{Ag}$ (I), (Fig. 1) a straight line was obtained passing through the origin. From the slope of line, the value of second order rate constant $\mathrm{k}^{\prime}$ was calculated to be $21.85 \mathrm{dm}^{3} / \mathrm{mol} / \mathrm{s}$.

Table 1. Dependence of pseudo first order rate constant $\left(\mathrm{k}_{\mathrm{obs}}\right)$ on $\left[\mathrm{Ag}^{+}\right]$

\begin{tabular}{ll}
\hline \hline$\left[\mathrm{Ag}^{+}\right] \times 10^{5} \mathrm{~mol} / \mathrm{dm}^{3}$ & $\mathrm{k}_{\text {obs }} 10^{4} / \mathrm{s}$ \\
\hline 4.16 & 9.0 \\
8.33 & 18.2 \\
12.5 & 28.0 \\
16.7 & 36.0 \\
\hline
\end{tabular}

$\left[\mathrm{Fe}\left(2,2^{\prime} \text {-bipy }\right)_{3}\right]^{2+}=5.0 \times 10^{-5} \mathrm{~mol} / \mathrm{dm}^{3} ;\left[\mathrm{S}_{2} \mathrm{O}_{8}{ }^{2-}\right]=4.16 \times 10^{-4}$ $\mathrm{mol} / \mathrm{dm}^{3} ; \mathrm{pH}=4.2 ; \mu=0.5 \mathrm{~mol} / \mathrm{dm}^{3} ; \mathrm{T}=303 \mathrm{~K}$.

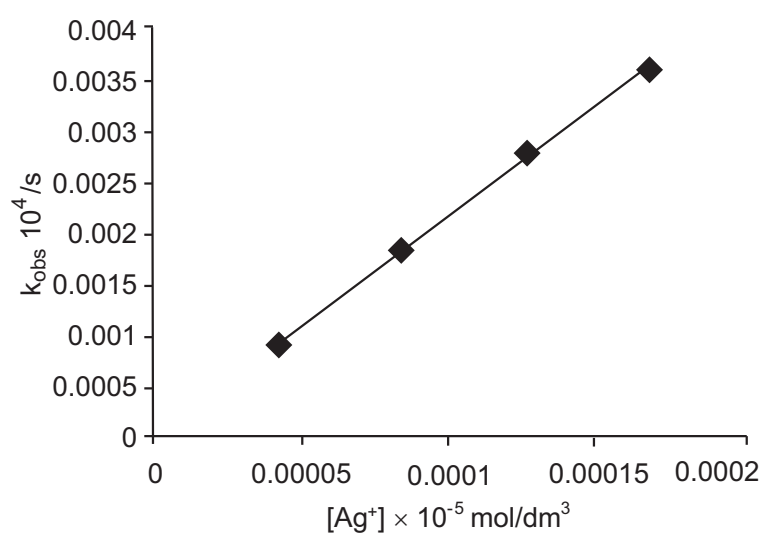

Fig. 1. Plot of pseudo first order rate constant ( $\left.\mathrm{k}_{\mathrm{obs}}\right)$ versus $\left[\mathrm{Ag}^{+}\right]$.

To study the effect of $\mathrm{S}_{2} \mathrm{O}_{8}{ }^{2-}$ concentration on the rate of reaction, kinetic runs were carried out at constant concentration of $\left[\mathrm{Fe}\left(2,2^{\prime}-\text { bipy }\right)_{3}\right]^{2+}$ and $\mathrm{Ag}^{+}$at $5.0 \times 10^{-5}$ and $4.16 \times 10^{-5} \mathrm{~mol} / \mathrm{dm}^{3}$, while the concentration of $\mathrm{S}_{2} \mathrm{O}_{8}{ }^{2-}$ was varied in the range $4.16 \times 10^{-4}-16.7 \times 10^{-4}$ $\mathrm{mol} / \mathrm{dm}^{3}$. It was observed that increasing concentration of peroxodisulphate ion also increases the value of $\mathrm{k}_{\text {obs }}$. When these values of $\mathrm{k}_{\mathrm{obs}}$ for different sets of experiments were plotted as a function of concentration of $\mathrm{S}_{2} \mathrm{O}_{8}{ }^{2-}$ (Fig. 2 and Table 2), a straight line was obtained passing 
through the origin. From the slope of line, the value of second order rate constant $\mathrm{k}^{\prime}$ was calculated to be $2.363 \mathrm{dm}^{3} / \mathrm{mol} / \mathrm{s}$.

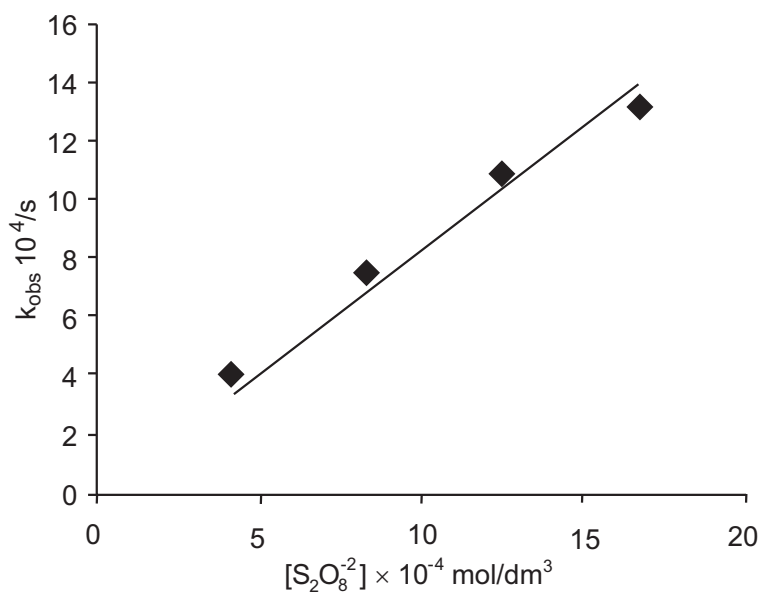

Fig. 2. Plot of pseudo first order rate constant $\left(\mathrm{k}_{\mathrm{obs}}\right)$ versus $\left[\mathrm{S}_{2} \mathrm{O}_{8}{ }^{2-}\right]$.

Table 2. Dependence of pseudo first order rate constant $\left(\mathrm{k}_{\mathrm{obs}}\right)$ on $\left[\mathrm{S}_{2} \mathrm{O}_{8}{ }^{2-}\right]$

\begin{tabular}{ll}
\hline \hline$\left[\mathrm{S}_{2} \mathrm{O}_{8}{ }^{2-}\right] \times 10^{4} \mathrm{~mol} / \mathrm{dm}^{3}$ & $\mathrm{k}_{\text {obs }} 10^{4} / \mathrm{s}$ \\
\hline 4.16 & 9.5 \\
8.33 & 20.7 \\
12.5 & 30.0 \\
16.7 & 38.7 \\
\hline \hline
\end{tabular}

$\overline{\left[\mathrm{Fe}\left(2,2^{\prime} \text {-bipy }\right)_{3}\right]^{2+}=5.0 \times 10^{-5} \mathrm{~mol} / \mathrm{dm}^{3} ;\left[\mathrm{Ag}^{+}\right]=4.16 \times 10^{-5}}$ $\mathrm{mol} / \mathrm{dm}^{3} ; \mathrm{pH}=4.2 ; \mu=0.5 \mathrm{~mol} / \mathrm{dm}^{3} ; \mathrm{T}=303 \mathrm{~K}$.

The complex concentration was varied between $(1.0 \times$ $\left.10^{-5}-5.0 \times 10^{-5} \mathrm{~mol} / \mathrm{dm}^{3}\right)$ at different $\mathrm{pH}(3.8-4.8)$ by keeping the concentration of $\mathrm{S}_{2} \mathrm{O}_{8}{ }^{2-}$ and $\mathrm{Ag}^{+}$constant at $4.16 \times 10^{-4}$ and $4.16 \times 10^{-5} \mathrm{~mol} / \mathrm{dm}^{3}$, respectively. Graphs of $\ln \left(\mathrm{A}_{\mathrm{t}}-\mathrm{A} \infty\right)$ versus time were plotted which show that there is no change in the value of rate constant. It means that change in concentration of complex does not influence the rate constant of oxidation of complex ion by peroxodisulphate (Table 3 ).

Table 3. Dependence of pseudo first order rate constant $\left(\mathrm{k}_{\text {obs }}\right)$ on $\left[\mathrm{Fe}\left(2,2^{\prime} \text {-bipy }\right)_{3}\right]^{2+}$

\begin{tabular}{ll}
\hline \hline$\left[\mathrm{Fe}\left(2,2^{\prime} \text {-bipy }\right)_{3}\right]^{2+} \times 10^{5} \mathrm{~mol} / \mathrm{dm}^{3}$ & $\mathrm{k}_{\text {obs }} 10^{4} / \mathrm{s}$ \\
\hline 1.0 & 1.9 \\
2.0 & 2.0 \\
3.0 & 1.9 \\
4.0 & 2.0 \\
5.0 & 2.0
\end{tabular}

$\left[\mathrm{S}_{2} \mathrm{O}_{8}{ }^{2-}\right]=4.16 \times 10^{-4} \mathrm{~mol} / \mathrm{dm}^{3} ;\left[\mathrm{Ag}^{+}\right]=4.16 \times 10^{-5} \mathrm{~mol} / \mathrm{dm}^{3}$; $\mathrm{pH}=4.2 ; \mu=0.5 \mathrm{~mol} / \mathrm{dm}^{3} ; \mathrm{T}=303 \mathrm{~K}$.
It has been observed that the rate is also independent of the hydrogen ion concentration in the $\mathrm{pH}$ range of 3.8 to 4.8 (Table 4 ).

Table 4. Dependence of pseudo first order rate constant ( $\left.\mathrm{k}_{\mathrm{obs}}\right)$ on $\left[\mathrm{H}^{+}\right]$

\begin{tabular}{ll}
\hline \hline $\mathrm{pH}$ & $\mathrm{k}_{\mathrm{obs}} 10^{4} / \mathrm{s}$ \\
\hline 3.8 & 2.0 \\
4.2 & 2.0 \\
4.4 & 1.5 \\
4.6 & 2.0 \\
4.8 & 2.0 \\
\hline \hline
\end{tabular}

$\overline{\left[\mathrm{Fe}\left(2,2^{\prime} \text {-bipy }\right)_{3}\right]^{2+}=5.0 \times 10^{-5} \mathrm{~mol} / \mathrm{dm}^{3} ;\left[\mathrm{S}_{2} \mathrm{O}_{8}{ }^{2-}\right]=4.16 \times 10^{-4}}$ $\mathrm{mol} / \mathrm{dm}^{3} ;\left[\mathrm{Ag}^{+}\right]=4.16 \times 10^{-5} \mathrm{~mol} / \mathrm{dm}^{3} ; \mu=0.5 \mathrm{~mol} / \mathrm{dm}^{3} ; \mathrm{T}=303 \mathrm{~K}$.

The dependence of the rate constant on the ionic strength $(\mu)$ of the medium was also studied by changing the ionic strength $\left(0.1-1.0 \mathrm{~mol} / \mathrm{dm}^{3}\right)$ using $\mathrm{Na}_{2} \mathrm{SO}_{4}$, while the remaining parameters were kept constant.

The plot of log k versus ( $\mu)^{1 / 2}$ (Fig. 3 and Table 5) was linear with a negative slope of -1.85 . Negative slope shows that the reactants bear opposite charges. As the reaction depends on $\mathrm{S}_{2} \mathrm{O}_{8}{ }^{2-}$ and $\mathrm{Ag}^{+}$, which carry -2 and +1 charges, respectively. Therefore, the resulting product of charges is suggested to be -2 . The results obtained by using Debye Huckel limiting law, $\log \mathrm{k}=\log \mathrm{k}_{\mathrm{o}}+1.02 \mathrm{z}_{\mathrm{A}} \mathrm{Z}_{\mathrm{B}}(\mu)^{1 / 2}$ are consistent with this value.

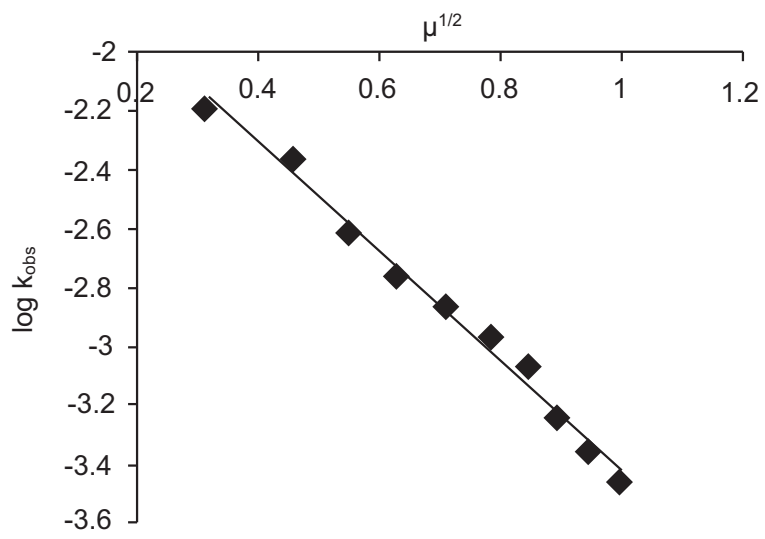

Fig. 3. Plot of $\log \mathrm{k}$ versus $(\mu)^{1 / 2}$.

Proposed mechanism for the $\mathrm{Ag}^{+}$catalysed oxidation of $\left[\mathbf{F e}\left(2,2^{\prime}-\mathrm{Bipy}\right)_{3}\right]^{2+}$ by $\mathbf{S}_{2} \mathbf{O}_{\mathbf{8}}{ }^{2-}$. On the basis of present investigations and the cited literature mentioned earlier, the mechanism is suggested to incorporate the following steps: 
Table 5. Variation of $\log \mathrm{k}$ versus $(\mu)^{1 / 2}$

\begin{tabular}{llll}
\hline \hline $\begin{array}{l}\mu\left(\mathrm{Na}_{2} \mathrm{SO}_{4}\right) \\
\mathrm{mol} / \mathrm{dm}^{3}\end{array}$ & $\begin{array}{l}\mathrm{k} \times 10^{3} \\
\mathrm{~mol} / \mathrm{dm}^{3} / \mathrm{s}\end{array}$ & $\mu^{1 / 2}$ & $\log \mathrm{k}$ \\
\hline 0.1 & 6.61 & 0.316 & -2.18 \\
0.2 & 4.17 & 0.447 & -2.38 \\
0.3 & 2.51 & 0.548 & -2.60 \\
0.4 & 1.78 & 0.632 & -2.75 \\
0.6 & 1.05 & 0.774 & -2.98 \\
0.7 & 0.83 & 0.837 & -3.08 \\
0.8 & 0.58 & 0.894 & -3.24 \\
0.9 & 0.46 & 0.949 & -3.34 \\
1.0 & 0.36 & 1.00 & -3.45 \\
\hline \hline
\end{tabular}

$\left[\mathrm{Fe}\left(2,2^{\prime} \text {-bipy }\right)_{3}\right]^{2+}=5.0 \times 10^{-5} \mathrm{~mol} / \mathrm{dm}^{3} ;\left[\mathrm{S}_{2} \mathrm{O}_{8}{ }^{2-}\right]=4.16 \times 10^{-4}$ $\mathrm{mol} / \mathrm{dm}^{3} ;\left[\mathrm{Ag}^{+}\right]=4.16 \times 10^{-5} \mathrm{~mol} / \mathrm{dm}^{3} ; \mu=0.5 \mathrm{~mol} / \mathrm{dm}^{3} ; \mathrm{T}=303 \mathrm{~K}$.

$$
\begin{aligned}
& \mathrm{Ag}^{+}+\mathrm{S}_{2} \mathrm{O}_{8}{ }^{2-} \stackrel{\text { slow }}{\longrightarrow}\left[\mathrm{Ag}_{2} \mathrm{~S}_{2} \mathrm{O}_{8}\right]^{-1} \\
& {\left[\mathrm{Ag}_{2} \mathrm{~S}_{2} \mathrm{O}_{8}\right]^{-1} \stackrel{\text { fast }}{\longrightarrow} \mathrm{Ag}^{2+}+\mathrm{SO}_{4}{ }^{2-}+\mathrm{SO}_{4}{ }^{1-}} \\
& \mathrm{SO}_{4}{ }^{1-}+\mathrm{Ag}^{+} \stackrel{\text { very fast }}{\longrightarrow} \mathrm{Ag}^{2+}+\mathrm{SO}_{4}{ }^{2-} \\
& {\left[\mathrm{Fe}\left(2,2^{\prime}-\text { bipy }\right)_{3}\right]^{2+}+\mathrm{Ag}^{2+} \stackrel{\text { fast }}{\longrightarrow}} \\
& {\left[\mathrm{Fe}\left(2,2^{\prime} \text {-bipy }\right)_{3}\right]^{3+}+\mathrm{Ag}^{+}}
\end{aligned}
$$

Equation (i) represents the slow association of $\mathrm{S}_{2} \mathrm{O}_{8}{ }^{2-}$ and $\mathrm{Ag}^{+}$ions, which results in formation of an ion pair $\left[\mathrm{Ag}_{2} \mathrm{~S}_{2} \mathrm{O}_{8}\right]^{-1}$. The next equation (ii) involves the decomposition of this ion pair into $\mathrm{Ag}^{2+}, \mathrm{SO}_{4}{ }^{2-}$ and $\mathrm{SO}_{4}{ }^{-}$is likely to be a faster one. The transient species $\mathrm{SO}_{4}{ }^{-}$ generated in equation (ii), oxidises $\mathrm{Ag}^{+}$ion as shown in equation (iii), this step as involving the transient species, is also fast. Equation (iv) shows the regeneration of $\mathrm{Ag}^{+}$by the fast reduction of $\mathrm{Ag}^{2+}$ by the $\left[\mathrm{Fe}\left(2,2^{\prime} \text {-bipy }\right)_{3}\right]^{2+}$ ion.

In the above suggested mechanism, equation (i) represents the rate determining step since the oxidation rate is first order with respect to the concentrations of both $\mathrm{Ag}^{+}$and $\mathrm{S}_{2} \mathrm{O}_{8}{ }^{2-}$ ions and hence the rate of formation of product would depend on the concentration of these ions.

The rate equation according to equation (i) will be,

$$
\text { Rate }=k^{\prime}\left[\mathrm{Ag}^{+}\right]\left[\mathrm{S}_{2} \mathrm{O}_{8}{ }^{2-}\right]
$$

where:

$\mathrm{k}^{\prime}=$ the second order rate constant, having the value $56810 \mathrm{dm}^{3} / \mathrm{mol} / \mathrm{s}$.

The above proposed mechanism is also supported by the plots of $\mathrm{k}_{\text {obs }}$ against $\mathrm{Ag}^{+}$ion concentration and that of kobs against $\mathrm{S}_{2} \mathrm{O}_{8}^{-2}$ concentration (Begum and Rasheed, 2001). These are straight line plots. In the first case the slope divided by $\mathrm{S}_{2} \mathrm{O}_{8}^{-2}$ concentration gives $\mathrm{k}^{\prime}=52526$ $\mathrm{dm}^{3} / \mathrm{mol} / \mathrm{s}$, whereas, in second case slope divided by $\mathrm{Ag}^{+}$ion concentration gives $\mathrm{k}^{\prime}=56810 \mathrm{dm}^{3} / \mathrm{mol} / \mathrm{s}$. The values of these second order rate constants are in good agreement with each other and strongly support first order dependence of reaction rate individually on $\mathrm{Ag}^{+}$ and $\mathrm{S}_{2} \mathrm{O}_{8}{ }^{2-}$ ion concentrations.

\section{References}

Anderson, J.M., Kochi, J.K. 1969. Silver (I) catalyzed decarboxylation of acids by peroxydisulfate. The role of Ag(II). Journal of American Chemical Society, 92: 1651-1659.

Begum, S., Rasheed, K.A. 2001. The kinetics of Ag(I) catalyzed oxidation of [Co(II)EDTA $]^{2-}$ by peroxydisulfate ion. Journal of Saudi Chemical Society, 5: 437-442.

Busari, A., Iyun, J.F., Idris, S.O. 2008. Kinetics and mechanism of silver(I) ion catalyzed oxidation of 3,7-(dimethylamino)phenothionium chloride (Methylene blue) by peroxydisulphate ion in aqueous nitric acid. International Journal of Pure \& Applied Sciences, 2: 10-16.

Cyfert, M. 1983. The influence of $\mathrm{Ag}^{+}$ions on the kinetics of oxidation of $\mathrm{Fe}(\mathrm{phen}){ }_{3}{ }^{2+}$ by peroxodisulfate in neutral aqueous solution. Inorganica Chimica Acta, 73: 135-139.

Fordham, J.W.L., Williams, L.H. 1951. The persulfateiron(II) initiator system for free radical polymerization. Journal of American Chemical Society, 73: 4855-4859.

House, D.A. 1962. Kinetics and mechanism of oxidations by peroxydisulfate. Chemical Reviews, 62: 185-203.

Latimer, W.M. 1952. The Oxidation States of the Elements and Their Potentials in Aqueous Solution, 78 pp., Prentice Hall, Eagle-Cliffs, New Jersey, USA.

Naim, M.A., Naqvi, I.I. 1981. Kinetics of decomposition of potassium peroxodisulphate in presence of silver nitrate. Journal of Science \& Technology, 5: 1-9.

Pryzstas, T.J., Sutin, N. 1973. Kinetic studies of anionassisted outer-sphere electron transfer reactions. Journal of the American Chemical Society, 95: 5545-5555.

Summer, S., Perveen, R., Naqvi. I.I. 2009. Investigation of redox reaction between $\left[\mathrm{Fe}\left(2,2^{\prime} \text {-bipy }\right)_{3}\right]^{2+}$ and $\mathrm{I}_{2}^{-}$., induced by $\mathrm{Cu}^{2+}$ and $\mathrm{I}^{-}$in aqueous medium. The Arabian Journal for Science and Engineering, 34: 75-85.

Taylor, R.C., Schilt, J.S. 1959. Infrared spectra of 1,10phenanthroline metal complexes in the rock salt region below $2000 \mathrm{~cm}^{-1}$. Journal of Inorganic \& Nuclear Chemistry, 9: 211-221.

Walling, C., Camaioni, D.M. 1978. Role of Ag(II) in silver-catalyzed oxidations by peroxydisulfate. Journal of Organic Chemistry, 43: 3266-3271.

Wilmarth, W.K., Haim, A. 1962. Peroxide Reaction Mechanisms, J. O. Edwards (ed.), 175 pp., John Wiley \& Sons, Inc., New York, USA. 